\title{
PELATIHAN PENGGUNAAN E-LEARNING SCHOOLOGY BAGI GURU SMK SE-KECAMATAN GEROKGAK
}

\author{
I Md. Dendi Maysanjaya ${ }^{1 a}$, I Made Ardwi Pradnyana ${ }^{1 b}$, I Made Edy Listartha1c, \\ Putu Yudia Pratiwi ${ }^{1 \mathrm{~d}}$, Ni Made Ayu Mita Kusumadewi ${ }^{1 \mathrm{e}}$, Irfan Walhidayah ${ }^{1 \mathrm{f}}$, I Gede \\ Agus Sukariana Yasa ${ }^{1 \mathrm{~g}}$, Kadek Wawan Cahyadi ${ }^{1 \mathrm{~h}}$ \\ ${ }^{1}$ Prodi Sistem Informasi, Jurusan Teknik Informatika, Universitas Pendidikan Ganesha

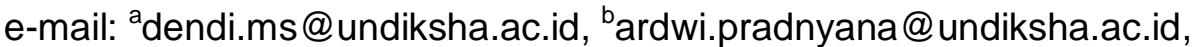 \\ listartha@undiksha.ac.id, dputuyudia.pratiwi@undiksha.ac.id,

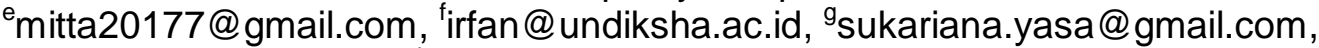 \\ hcahyadywawan@gmail.com
}

\begin{abstract}
Abstrak
E-learning merupakan terobosan dalam meningkatkan kualitas pembelajaran. Beragam jenis Learning Management System (LMS) telah dikembangkan dan digunakan, salah satunya adalah Schoology. Meski demikian masih ada guru, khususnya guru SMK di Kecamatan Gerokgak yang sama sekali belum pernah menggunakan LMS. Sementara ada beberapa guru yang sudah pernah menggunakan LMS, menyatakan bahwa LMS yang digunakan masih memiliki beberapa kelemahan dan cenderung tidak stabil. Berdasarkan permasalahan tersebut dirancanglah sebuah kegiatan pelatihan untuk guru SMK sebanyak 46 orang, dan berasal dari beberapa SMK di Kecamatan Gerokgak. Kegiatan pengabdian ini dipandu oleh 1 orang instruktur yang didamping oleh 3 orang dosen dan 7 orang mahasiswa dari Prodi Sistem Informasi Undikhsa. Metode pengabdian yang dilakukan terdiri atas lima tahap kegiatan, yang terdiri atas penentuan lokasi, persiapan, pelatihan, evaluasi, dan pelaporan kegiatan. Dari hasil pengabdian yang dilakukan, sebanyak $95,7 \%$ menyatakan sudah bisa menggunakan fitur Schoology dan merasakan kebermanfataannya, serta $73,9 \%$ menyatakan akan menggunakannya sebagai media pendukung proses pembelajaran.
\end{abstract}

Kata kunci: pelatihan, e-learning, Schoology, guru smk

\begin{abstract}
E-learning is a breakthrough in improving the quality of learning. Various types of learning management systems (LMS) have been developed and used, one of which is Schoology. Nevertheless, there are still teachers, especially vocational teachers in Gerokgak Subdistrict who have never used LMS. While several teachers have used LMS, the LMS stated that it still has some weaknesses and tends to be unstable. Based on these problems a training activity was designed for as many as 46 vocational school teachers and came from several vocational schools in Gerokgak District. This service activity was guided by 1 instructor and also it was accompanied by 3 lecturers and 7 students from the Information System Study Program, Undiksha. The service method used consists of five stages of activity, consisting of determining the
\end{abstract}




\section{Jurnal Widya Laksana, Vol.10, No.2, Agustus 2021}

location, preparation, training, evaluation, and reporting of activities. From the results of devotion conducted, as many as $95.7 \%$ stated that they could use the Schoology features and felt their usefulness, and $73.9 \%$ said they would use them as a media to support the learning process.

Keywords: coaching, e-learning, Schoology, vocational high school teachers

\section{PENDAHULUAN}

Pertumbuhan pengguna internet di Indonesia sangat pesat. Pesatnya pertumbuhan internet diikuti dengan sejumlah tren positif khususnya dibidang pendidikan yaitu penggunaan sistem belajar online atau yang lebih dikenal dengan istilah e-learning. Elearning diklaim memiliki kelebihan bila dibandingkan dengan pembelajaran konvensional yang biasa dilakukan di kelas (Burhani, 2018), (Hidayat, 2018), (Ratnasari, 2012). Kelebihan tersebut diantaranya lebih menghemat biaya dan waktu belajar. Selain itu, keterbatasan jumlah guru dibandingkan siswa serta kebutuhan yang besar untuk buku teks dapat diatasi dengan bantuan pembelajaran daring ini. Mengetahui dampak positif yang ditimbulkan, sudah banyak sekolah yang mulai mengimplementasikan $e$ learning sebagai alat bantu atau pelengkap proses pembelajaran konvensional atau offline.

Sekolah-sekolah atau institusi pendidikan sebagian besar sudah mulai melakukan investasi fasilitas berbasis teknologi informasi seperti LCD proyektor, kumputer untuk laboratorium komputer, internet (WIFI dan LAN) dan lainnya untuk menunjang proses pendidikan. Pesatnya perkembangan teknologi dan pertumbuhan investasi tersebut juga harus dibarengi dengan kemampuan dan keterampilan guru dalam menggunakan utamanya dalam proses pembelajaran dikelas. Pada era yang serba digital ini, guru tidak hanya dituntut memiliki kompetensi dan strategi pembelajaran yang baik, namun juga harus mampu mengkombinasikan teknologi informasi dan komunikasi dalam proses pembelajaran.

Pemanfaatan e-learning di sekolah-sekolah sebagai salah satu pelengkap pembelajaran semakin meningkat. E-learning menjadi alternatif media pembelajaran yang lebih fleksibel segingga pembelajarandapat dilakukan secara sinkronus dan asinkronus serta dimana saja dan kapan saja (Luaran, dkk. 2014), (Shahabadi, dkk. 2015), (Xie, dkk. 2018). Namun demikian tidak semua sekolah mampu mengimplementasikan e-learning. Berbagai kendala terjadi dalam implementasinya, salah satunya minimnya pengetahuan dan keterampilan guru terkait pemanfaatan teknologi informasi khususnya $e$ learning. Selain itu, keberadaan fasilitas dan tenaga yang menguasai teknologi di sekolah juga turut mendukung sulitnya implementasi e-learning. Misalnya saja tidak tersedianya server untuk menampung konten pembelajaran e-learning.

Selain itu, kenyataan di lapangan yang terjadi adalah masih ada guru yang sama sekali belum pernah menggunakan e-learning untuk membantu dalam proses pembelajaran. 
Untuk mengetahui kondisi penggunaan e-learning pada guru, dilakukan survei terhadap 46 orang guru SMK di Kecamatan Gerokgak. Berdasarkan survei yang dilakukan, dari 46 responden, sekitar $37 \%$ menyatakan tidak pernah memanfaatkan e-learning untuk membantu dalam proses pembelajaran, sebagaimana yang tertera pada Gambar 1. Dari 63\% responden yang menyatakan pernah menggunakan e-learning, diberikan pertanyaan terkait jenis e-learning yang pernah digunakan, dengan hasil seperti Gambar 2.

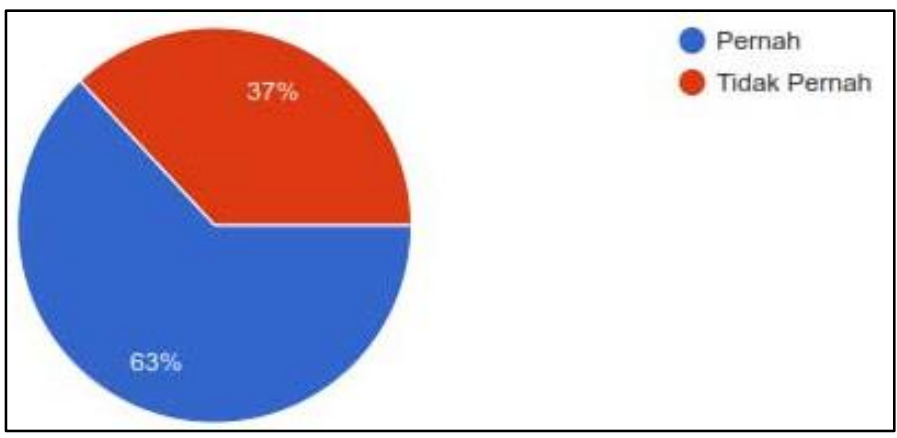

Gambar 1. Kondisi Penggunaan E-Learning Pada Guru SMK di Kecamatan Gerokgak

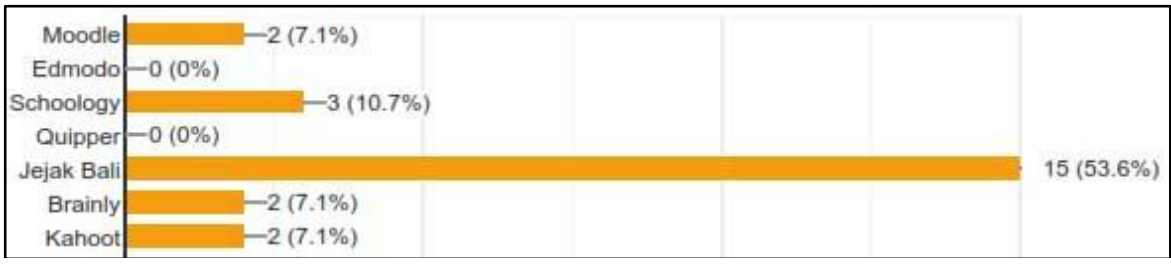

Gambar 2. Respon Jenis E-Learning yang Pernah Digunakan

Berdasarkan informasi dari Gambar 2, tampak bahwa Jejak Bali merupakan jenis LMS yang paling banyak digunakan. Hal ini karena merupakan hasil pengembangan dari program Pemerintah Provinsi Bali. Hanya saja dalam penerapannya, guruguru masih banyak menemukan kendala, serta kurang stabilnya aplikasi yang dikembangkan, hingga lambat laun semakin sedikit yang menggunakan media LMS tersebut.

Saat ini, berbagai alternatif pemecahan masalah tersebut sudah tersedia. Salah satu alternatif Learning Management System (LMS) yang bersifat gratis dan tidak memberatkan sekolah karena harus menyiapkan server sudah tersedia. Salah satunya media e-learning tersebut adalah Schoology. Schoology adalah situs jaringan sosial tempat berbagi data, event, jadwal dan lain sebagainya terkait pendidikan yang dikembangkan untuk para guru dan murid (Aidid, 2018), (Eka, 2016).

Schoology merupakan salah satu platform inovatif yang dibuat 
berdasarkan inspirasi dari media sosial Facebook yang ditujukan untuk kepentingan pendidikan (Rinenggo \& Murdiono). Schoology sebagai platform pembelajaran online memberikan lebih banyak kesempatan untuk interaksi antara guru dan siswa, siswa dan teman sebayanya, serta siswa dan materi (Çepik, dkk., 2016).

Schoology memiliki fitur yang mirip dengan aktivitas media sosial, sehingga memberikan peluang pembelajaran yang lebih sejalan dengan kebiasaan sehari-hari siswa yang cenderung menyukai kegiatan media sosial (Sari, dkk., 2020). Schoology terdiri dari dua konteks utama yaitu komunikasi interaktif dan pertukaran informasi akademik (Rama, dkk., 2020). Guru dapat membuat pertanyaan diskusi, kelompok kolaboratif, atau papan untuk tugas yang memungkinkan interaksi dinamis antara siswa dan guru mereka.

Beberapa penelitian yang telah dilakukan menunjukkan bahwa Schoology dapat meningkatkan aktivitas dan minat belajar siswa serta meningkatkan hasil belajar (Rosalina, 2018), (Warsiti, dkk., 2019), (Rachman \& Arbain, 2019), (Sitinjak, 2020). Hal ini didukung oleh tampilan Schoology yang menarik dan lebih interaktif.

Schoology memiliki berbagai fitur yang memungkinkan guru untuk melaksanakan berbagai aktivitas online yang menunjang proses pembelajaran (Dewi, dkk., 2018), (Shavab, 2018), (Feridanto \& Dwiniasih, 2019). Fiturfitur yang ada di Schoology diantaranya upload materi pelajaran berupa teks, gambar atau audiovisual, membuat grup belajar, laporan tugas, diskusi antara guru dengan siswa atau siswa dengan siswa, grafik nilai siswa, kuis, dan memberikan ujian. Selain itu, kelebihan Schoology adalah orang tua murid dapat melihat aktivitas anaknya dengan membuat akun dan login sebagai parent (orang tua). Orang tua dapat terlinat dan melihat nilai anak mereka dan berintekasi dengan guru (Apriliani, dkk., 2019).

Berdasarkah hal tersebut, maka dirancanglah sebuah program pengabdian yang bertujuan untuk menambah wawasan guru-guru, khususnya guru SMK di Kecamatan Gerokgak, dengan memberikan pelatihan penggunaan e-learning dengan jenis media Schoology.

\section{METODE}

Dalam melaksanakan kegiatan pengabdian, dirancang suatu metode yang terbagi ke dalam lima tahap, seperti Gambar 3. Kegiatan dimulai dari penentuan lokasi pengabdian, dengan melakukan survei dan pemberian pretest, guna melihat kebutuhankebutuhan yang memang sesuai kondisi guru-guru SMK di Kecamatan Gerokgak. Selanjutnya dari hasil analisis situasi yang dilakukan, dilanjutkan dengan tahap persiapan, untuk menyiapkan kebutuhan pelatihan yang akan dilakukan.

Setelah semua persiapan selesai dilakukan, tahap selanjutnya adalah melaksanakan pelatihan yang telah dirancang. Dari kegiatan pelatihan yang telah dilaksanakan, dilanjutkan dengan pemberian post-test untuk mengukur keterserapan materi pelatihan.

Sebagai penutup dari rangkaian pengabdian yang dilakukan, pembuatan laporan dan publikasi ilmiah dilakukan sebagai bentuk 
pertanggungjawaban atas keseluruhan kegiatan pengabdian yang telah dilaksanakan.

\section{PENENTUAN LOKASI}

- Survei

- Pre-Test

\section{PERSIAPAN}

- Materi dan Modul

- Koordinasi dengan Pihak Sekolah

- Peyebara Surat Undangan

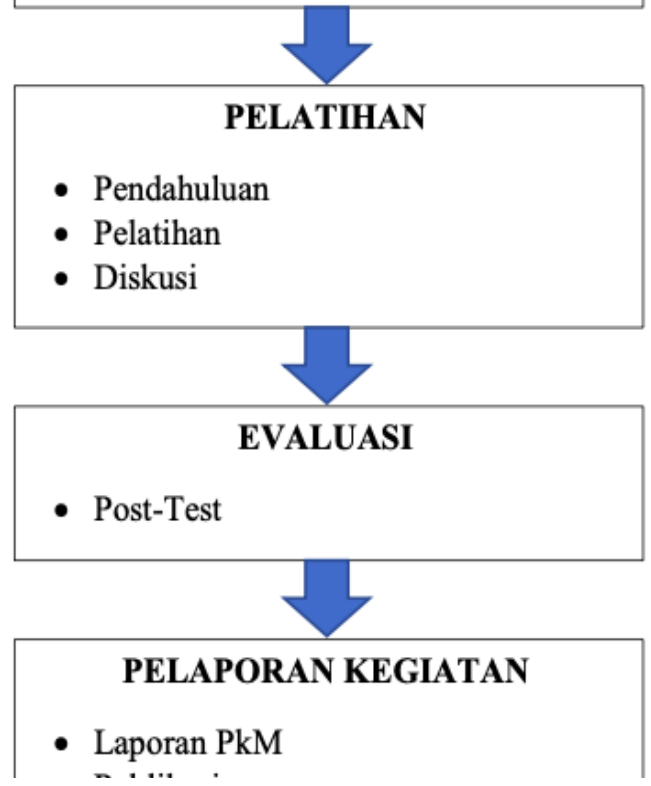

Gambar 3. Metode Pengabdian

\section{HASIL DAN PEMBAHASAN}

Kegiatan pengabdian dilaksanakan dengan memberikan pelatihan pada guru SMK di Kecamatan Gerokgak sebanyak 46 orang, dan berasal dari empat sekolah, yakni SMK Negeri 1 Gerokgak (penyedia tempat pengabdian), SMKS Nusa Dua
Gerokgak, SMKS Istiqlal Gerokgak, dan SMK PGRI Gerokgak.

Pengabdian ini merupakan serangkaian kegiatan SIFORS Mengabdi. SIFORS Mengabdi adalah kegiatan pengabdian kepada masyarakat yang diinisiasi oleh Prodi Sistem Informasi Undiksha. Kegiatan ini melibatkan civitas akademika di lingkungan Prodi Sistem Informasi, mulai dari staf dosen hingga mahasiswa. Tujuan dari kegiatan ini selain memberikan pelayanan kepada masyarakat sesuai permasalahan yang akan dipecahkan, juga sebagai bentuk sosialisasi untuk Prodi Sistem Informasi, mengingat prodi ini baru yang berdiri tahun 2018 .

Instruktur dalam pelatihan penggunaan e-learning Schoology bagi guru SMK se-Kecamatan Gerokgak ini adalah Bapak I Made Ardwi Pradnyana yang juga merupakan dosen di Prodi Sistem Informasi Undiksha. Kegiatan pelatihan ini didampingi oleh 3 orang dosen dan 7 orang mahasiswa dari Prodi Sistem Informasi. Pendamping dari dosen dan mahasiswa ini bertujuan untuk membantu guru-guru saat praktek menggunakan Schoology.

Kegiatan diawali dengan pemaparan terkait LMS secara umum seperti yang telihat pada Gambar 4, dan dilanjutkan dengan penjelasan tentang Schoology. Pada saat penjelasan tentang Schoology, guruguru diajak untuk langsung mempraktekkan dalam menggunakan Schoology, seperti yang terlihat pada Gambar 5. 


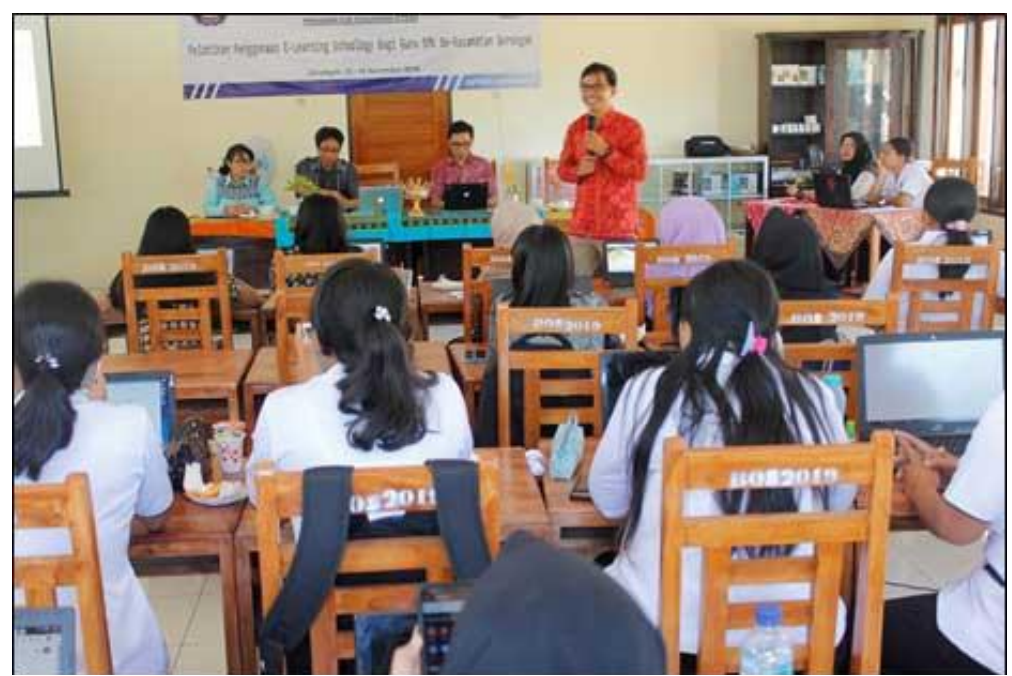

Gambar 4. Instruktur menjelaskan materi konsep e-learning

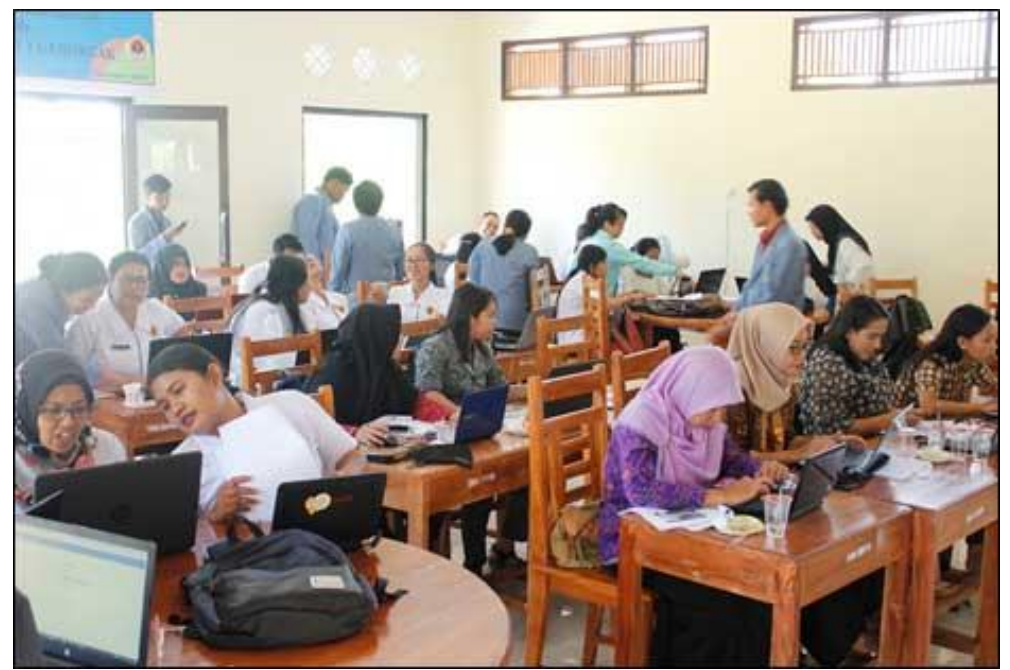

Gambar 5. Guru praktek menggunakan Schoology dipandu instruktur dan pendamping

Pada akhir kegiatan, guru-guru diberikan post-test guna mengukur keberhasilan dari pelatihan yang telah diberikan. Aspek yang diukur meliputi tiga hal, yakni 1) kemampuan dalam menggunakan fitur-fitur Schoology, 2) kebermanfaatan Schoology dalam membantu proses pembelajaran, dan 3) keinginan untuk menggunakan Schoology, yang hasilnya dapat dilihat melalui grafik pada Gambar 6, Gambar 7, dan Gambar 8 secara terurut. 
Jurnal Widya Laksana, Vol.10, No.2, Agustus 2021

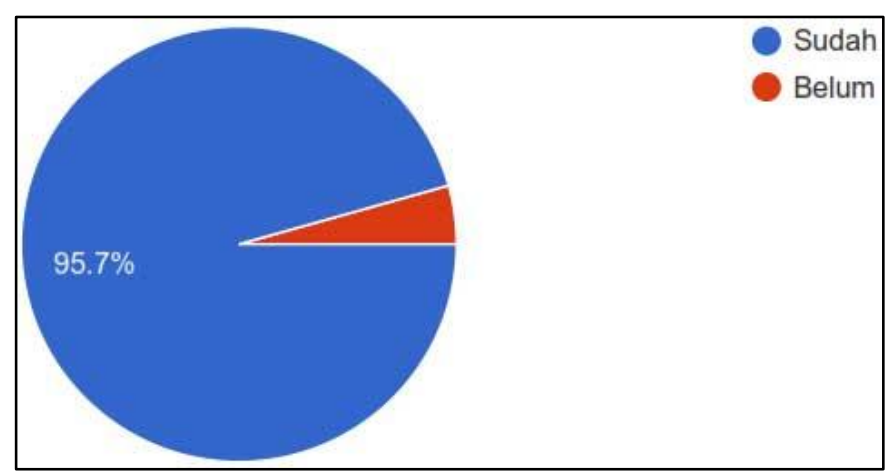

Gambar 6. Kemampuan Menggunakan Fitur Schoology

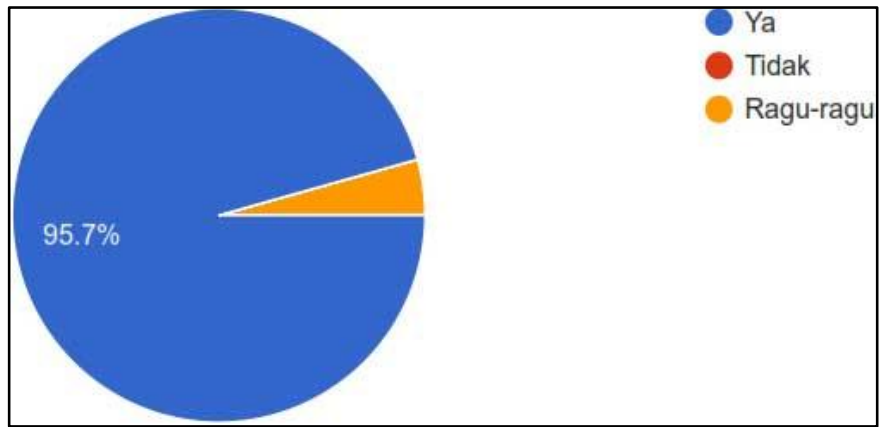

Gambar 7. Kebermanfaatan Schoology dalam Menunjang Pembelajaran

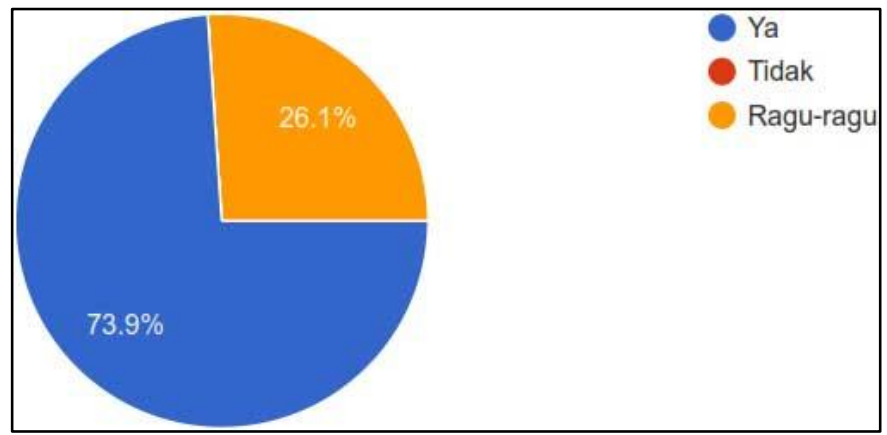

Gambar 8. Keinginan Penggunaan Schoology

Berdasarkan hasil respon pada Gambar 6, dari 46 guru SMK di Kecamatan Gerokgak yang mengikuti pelatihan, sebanyak 95,7\% menyatakan sudah bisa menggunakan dan memahami fitur-fitur yang ada di Schoology, sementara 4,3\% menyatakan belum secara fasih bisa menggunakan. Hal ini disebabkan durasi waktu pelatihan yang relatif 
singkat, sehingga menyebabkan kesulitan dalam memahami fitur-fitur yang ada dalam Schoology. Selain itu, karena belum dimilikinya pengalaman dalam menggunakan LMS secara umum, menyebabkan proses adaptasi relatif lama. Namun secara umum, pelatihan yang dilakukan bisa membuat guru-guru memahami fitur-fitur yang ada dalam LMS Schoology.

Untuk respon terkait kebermanfaatan LMS Schoology jika digunakan dalam proses pembelajaran, sesuai hasil pada Gambar 7, sebanyak 95,7\% responden menyatakan bahwa Schoology dapat digunakan untuk menunjang dalam proses pembelajaran. Hal ini disebabkan kemudahan fitur-fitur yang ada pada Schoology, sehingga memudahkan guru dalam mengelola kegiatan pembelajaran. Sementara 4,3\% menyatakan ragu-ragu, yang kemungkinan disebabkan masih kurang fasihnya mereka dalam menggunakan dan memahami fitur-fitur yang dimiliki oleh Schoology.

Sementara terkait keberlanjutan guru dalam menggunakan LMS Schoology nantinya berdasarkah respon pada Gambar 8, diperoleh hasil 73,9\% menyatakan akan menggunakan Schoology dan $26,1 \%$ menyatakan masih ragu-ragu. Hasil ini cenderung disebabkan kondisi yang mengharuskan guru-guru menggunakan LMS yang disediakan pemerintah, meskipun masih memiliki kendala dalam penggunaannya. Sementara jika dibandingkan dengan Schoology yang stabil, maka timbullah kesan ragu untuk menggunakan yang mana. Namun lebih dari 50\% menyatakan akan menggunakan
Schoology, karena sangat merasa terbantu dan kemudahan ketika menggunakan fitur-fitur yang dimiliki Schoology.

Kontribusi yang telah diberikan pada kegiatan pengabdian ini yaitu memperkenalkan e-learning Schoology kepada guru-guru SMK di Kecamatan Gerokgak. E-learning ini dapat digunakan sebagai alternatif media untuk proses belajar mengajar yang lebih interaktif sehingga metode pembelajaran lebih bervariasi dan diharapkan dapat meningkatkan minat belajar siswa. Selain itu, pelatihan ini melibatkan perwakilan guru-guru SMK se-Kecamatan Gerokgak yang nantinya diharapkan guru-guru yang mengikuti pelatihan ini dapat menyalurkan ilmunya kepada guru-guru lainnya di sekolah masing-masing sehingga seluruh guru di SMK Gerokgak dapat menggunakan fasilitas e-learning Schoology ini.

Namun dalam pelaksanaan pengabdian ini masih terdapat kendala. Kendala yang dialami guru-guru selama kegiatan pengabdian ini adalah mereka masih belum familiar dengan fitur-fitur yang ada pada Schoology sehingga membutuhkan waktu lebih lama untuk mencari letak fitur yang diinginkan dan cara menggunakan fitur-fitur tersebut. Namun, masing-masing guru telah diberikan modul yang dapat digunakan sebagai panduan dalam menggunakan Schoology.

\section{KESIMPULAN}

Berdasarkan uraian yang telah disampaikan pada bagian Hasil dan Pembahasan, secara umum dapat disimpulkan bahwa kegiatan pengabdian berupa pemberian 
pelatihan e-learning dengan menggunakan Schoology sudah berhasil dan bisa menjadi solusi atas permasalahan yang muncul di lapangan. Sesuai respon pada post-test yang dilakukan, hampir seluruhnya menyatakan pelatihan yang diberikan sangat bermanfaat, khususnya dalam membantu proses pembelajaran. Sebagai bahan masukan terhadap kendala yang dialami pada kegiatan pengabdian ini yaitu hendaknya ada kegiatan pendampingan pasca kegiatan pelatihan, sehingga guru-guru bisa merasa lebih mantap lagi dalam menggunakan Schoology untuk membantu proses pembelajaran.

\section{DAFTAR PUSTAKA}

Aidid, S. (2018). Asyik, Kita Bisa buat E-Learning Schoology Iho!. Retrieved December 6, 2019, form

https://www.kompasiana.com/su mayazaki/5bcf8686ab12ae1692 3753e2/asyiiik-kita-bisa-buat-elearning-schoology-lho

Aprilliani, A., Asib, A., \& Ngadiso. (2019). Schoology as a Learning Media Platform for Writing Skill, Implications to Teachers and Students. 3rd English Language and Literature International Conference (ELLIC). Vol. 3. 8994

Burhani, R. (2018). Laporan: Metode belajar daring semakin diminati. Retrieved January 8, 2019, from https://www.antaranews.com/be rita/677626/laporan-metodebelajar-daring-semakin-diminati

Çepik, Ş., Gönen, K., \& Sazak, M. K. (2016). ELT instructors" attitudes towards the use of Blended Learning in tertiary level English language programs. International Journal of Human Sciences, 13(1), 1715-1730.

Dewi, G. P. R., Adnyani, L. D. S., \& Piscayanti, K. S. (2018). Students' Perception on the Design of Asynchronous Online Discussion Using Schoology in English Language Education Ganesha University of Education. International Journal of Language and Literature. 2(2). 60-65.

Eka. (2016). Media E-Learning Schoology. Retrieved December 6, 2019, from http://ekateddytkj2.blogspot.com /2016/05/pengertianschoology.html

Ferdianto, F. \& Dwiniasih. (2019). Learning Management System (LMS) schoology: Why it's important and what it looks like. International Symposium on Sciences, Engineering, and Technology. IOP Conf. Series: Journal of Physics: Conf. Series 1360 (2019) 012034.

Hidayat, M. W. (2018). E-Learning Makin Menarik Perhatian di 2018. Retrieved January 8, 2019, from https://www.liputan6.com/tekno/ read/3226423/e-learning-makinmenarik-perhatian-di-2018

Luaran, J. E. Samsuri, N. N., Nadzri, F. A., \& Rom, K. B. M. (2014). A study on the student's perspective on the effectiveness of using e-learning. Procedia Social and Behavioral Sciences 
Jurnal Widya Laksana, Vol.10, No.2, Agustus 2021

123 (2014) 139 - 144.

Rachman, D., Sunarti \& Arbain. (2019). The Effect of E-learning Based Schoology on the Learning Outcomes in Nursing Program. IJOTL-TL. 4(3). 163-172.

Rama, A. N., Rahim, A., Alberth (2018). The Use of Schoology to Enhance Students' Reading Comprehension at Lakidende University. Journal of Language Education and Educational Technology, 3(1).

Ratnasari, A. (2012). Studi Pengaruh Penerapan E-Learning Terhadap Keaktifan Mahasiswa Dalam Kegiatan Belajar Mengajar Studi Kasus Universitas Mercu Buana Jakarta. In Seminar Nasional Aplikasi Teknologi Informasi 2012 (SNATI 2012) Yogyakarta.

Rinenggo, A. \& Murdiono, M. (2019). Utilization of Schoology for the Development of PPKn Teaching Materials Based on E-Learning. Advances in Social Science, Education and Humanities Research, volume 398. 2nd International Conference on Social Science and Character Educations. 14-19.

Rosalina, Mira. (2018). Analysis the Use of Schoology E-Learning Towards Students' Learning Motivation Enhancement in STKIP Surya. Indonesian Journal of Science and Education. 2(1). 89-95.

Sari, L., Sulisworo, D., Toifur, M., \& Rahman, N. H. A. (2020). Effects of Schoology Online Cooperative Learning to
Learning Achievement. International Journal Of Scientific \& Technology Research, 9(2), 99-103.

Shahabadi, M. M. \& Uplane, M. (2015). Synchronous and asynchronous e-learning styles and academic performance of e-learners. Procedia - Social and Behavioral Sciences 176 (2015) 129 - 138.

Shavab, O. A. K. (2018). SchoologyBased Learning Management System (LMS) as an Innovation in History Learning. $2^{\text {nd }}$ International Conference on History Education 2018. 174179.

Sitinjak, A. A. (2020). The Effect of Learning Method Schoology Applications and Learning Style on Student Learning Outcomes. International Journal for Innovation Education and Research. 8(6). 113-119.

Warsito, M. B., Haryono \& Wibawanto, H. (2019). E-Learning Development Based on Schoology for Subject of Information and Communication Technology Grade VII using Flipped-Learning Approach. Innovative Journal of Curriculum and Educational Technology. 8(1). 1-10.

Xie, H., Liu, W., Bhairma, J. \& Shim, E. (2018). Analysis of Synchronous and Asynchronous E- Learning Environments. 3rd Joint International Information Technology, Mechanical and Electronic Engineering Conference. 270-274. 